\title{
A design aid for sizing filter strips using buffer area ratio
}

\author{
M.G. Dosskey, M.J. Helmers, and D.E. Eisenhauer
}

\begin{abstract}
Nonuniform field runoff can reduce the effectiveness of filter strips that are a uniform size along a field margin. Effectiveness can be improved by placing more filter strip where the runoff load is greater and less where the load is smaller. A modeling analysis was conducted of the relationship between pollutant trapping efficiency and the ratio of filter strip area to upslope contributing area, i.e., buffer area ratio. The results were used to produce an aid for designing filter strips having consistent effectiveness along field margins where runoff load is nonuniform. Simulations using the process-based Vegetative Filter Strip Model show that sediment and water trapping efficiencies of a filter strip increase nonlinearly as the buffer area ratio gets larger. Site characteristics, including slope, soil texture, and upslope soil cover management practices, help to define this relationship more accurately. Using the Vegetative Filter Strip Model simulation results, a graphical design aid was developed for estimating the buffer area ratio required to achieve specific trapping efficiencies for different pollutants under a broad range of agricultural site conditions. A single graph was produced showing simulation results for seven scenarios as a family of lines that divide the full range of possible relationships between trapping efficiency and buffer area ratio and into fairly even increments. Simple rules guide the selection of one line that best describes a given field situation by considering slope, soil texture, and field cover management practices. Relationships for sediment-bound and dissolved pollutants are interpreted from the Vegetative Filter Strip Model results for sediment and water. The design aid is easy to use, accounts for several major variables that determine filter strip performance, and is based on a validated, process-based, mathematical model. The use of this design aid will enable a more precise fit between filter size and runoff load where runoff from agricultural fields is nonuniform.
\end{abstract}

Key words: models—nonpoint source pollution — precision conservation — surface runoffvariable-width buffers — vegetative buffers — water quality — watershed planning

Filter strips are commonly installed for improving and protecting water quality in agricultural watersheds. Filter strips (Code 393) reduce the load of sediment, nutrients, and other pollutants in overland runoff from fields by promoting infiltration and sediment deposition (Haan et al. 1994; USDA 1997). Typically, they are designed to have a constant width (parallel to flow) along a field margin, and maximum pollutant trapping efficiency is achieved when field runoff is uniformly dispersed across the entire filter strip (USDA 1997). Several design methods have been developed for determining the appropriate width for a filter strip treating spatially uniform runoff (see review in Dosskey et al. 2008). However, researchers have observed that surface runoff commonly concentrates in fields and flows mainly through only small portions of filter strips (Dillaha et al. 1986, 1989; Fabis et al. 1993; Dosskey et al. 2002). Field, plot, and modeling studies have confirmed that constant-width filter strips are less effective for trapping sediment, nitrogen, and phosphorus if concentrated flow occurs than if the flow is uniform (Daniels and Gilliam 1996; Dickey and Vanderholm 1981; Dillaha et al. 1988, 1989; Dosskey et al. 2002).

A design method is needed for sizing filter strips in landscapes where runoff load is nonuniform. Dosskey et al. (2005) proposed a variable-width approach. They noted that reduced trapping efficiency of a constantwidth filter strip stems from the strip being too narrow at locations receiving greater run- off loads. Cost effectiveness of the filter strip is also reduced by installing too much filter in locations that receive little or no runoff and consequently contribute little to reducing runoff load from the field as a whole. A filter strip would be more effective if it was designed to be wider where the runoff load is greater and narrower where the runoff load is smaller. The concept of matching the size of filter strip to the size of the runoff load is not new. Other researchers have proposed that filter strips be designed based on the ratio of filter strip area to upslope contributing area, or buffer area ratio, after noting strong relationships between this ratio and trapping efficiency for sediment, nitrogen, and phosphorus (Overcash et al. 1981; Mander et al. 1997; Bren 1998, 2000). In this approach, the contributing area is a surrogate for the size of runoff load, and the filter area is a surrogate for the trapping capability of the filter strip. Dosskey et al. (2002) used the Vegetative Filter Strip Model (VFSMOD) (MuñozCarpena and Parsons 2000) to demonstrate that sediment trapping efficiency increases as the buffer area ratio increases. However, the magnitude of trapping efficiency for a given buffer area ratio varies with site conditions such as slope, soil texture, and field practices that also determine the magnitude of the runoff load from a field and the trapping capability of a filter strip (Helmers et al. 2002; Muñoz-Carpena and Parsons 2004). Dosskey et al. (2005) described how the buffer area ratio could be employed to design variable-width filter strips, but they noted that a quantitative design model that relates the area ratio to pollutant trapping hasn't been developed. Since watershed planners often express desired levels of impact in terms of a percentage reduction of runoff load that is required to meet some regulatory limit (e.g., total maximum daily load), a useful design model would identify the buffer area ratio of filter strip that achieves that percentage.

The objectives of this study were to evaluate relationships between pollutant

Michael G. Dosskey is a research ecologist with the USDA Forest Service, Southern Research Station, National Agroforestry Center in Lincoln, Nebraska. Matthew J. Helmers is an associate professor in the Department of Agricultural and Biosystems Engineering at lowa State University, Ames, lowa. Dean E. Eisenhauer is a professor in the Department of Biological Systems Engineering at the University of Nebraska, Lincoln, Nebraska. 


\section{Figure 1}

Relationship between sediment trapping efficiency and buffer area ratio for overland flow exhibiting different degrees of flow convergence (CR) in a filter strip. The regression line represents the scenario where no flow convergence occurs $(C R=0)$. Larger values for $C R$ represent greater degrees of flow convergence. Flow convergence represented by $C R=0$ and $C R=0.43$ are illustrated on the right. In the illustration, the gray area represents the shape of the water flow path from the upper end of a filter strip to the lower end. Data were adapted from Helmers et al. (2005).
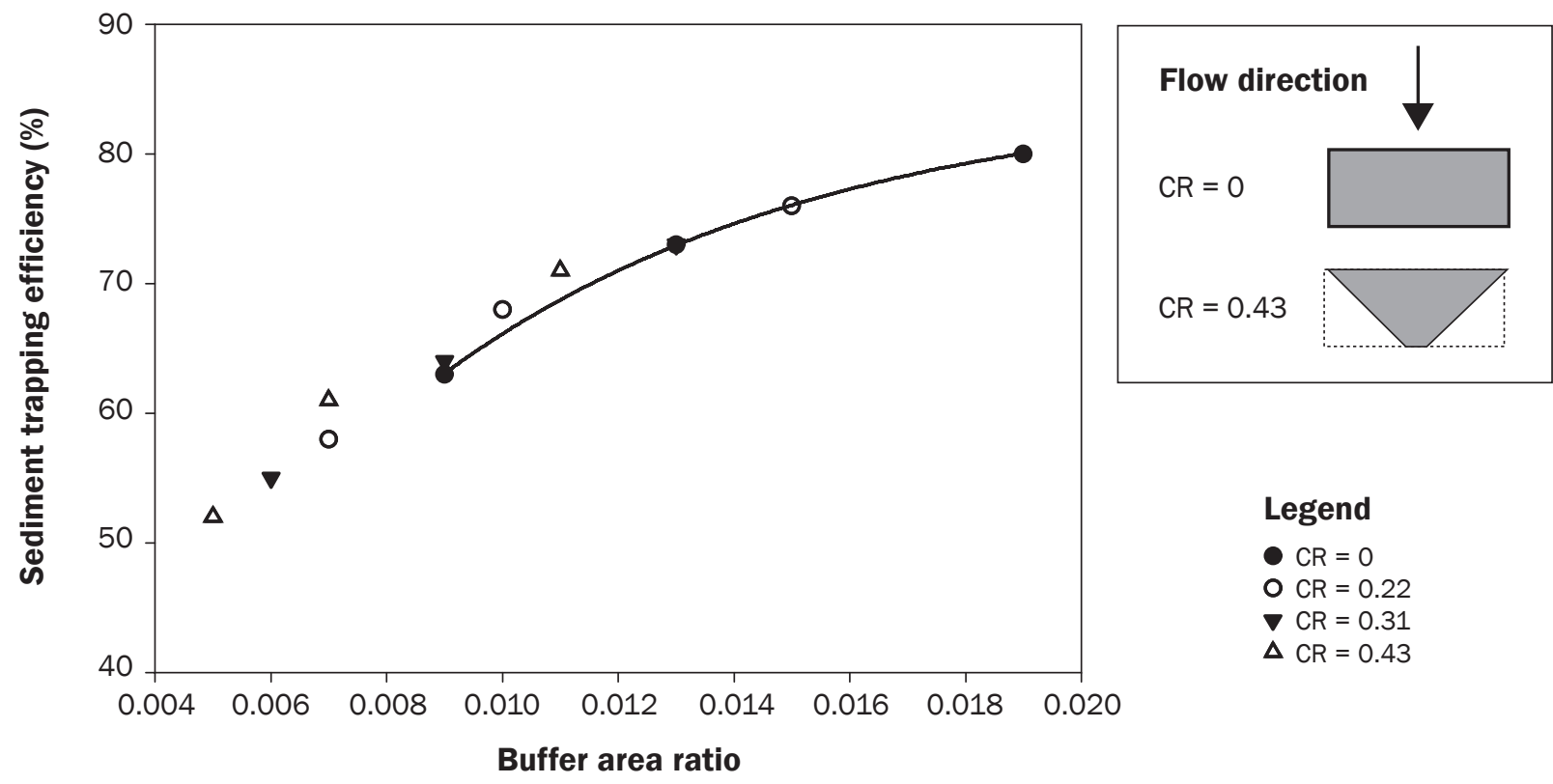

Legend

- $\mathrm{CR}=0$

$\mathrm{O} C \mathrm{CR}=0.22$

$\nabla \mathrm{CR}=0.31$

$\Delta \mathrm{CR}=0.43$

trapping efficiency of a filter strip and buffer area ratio, and from those results, produce a design aid that can be used to design filter strips to achieve a desired level of trapping efficiency along fields where nonuniform runoff occurs.

\section{Materials and Methods}

Modeling Approach. The Vegetative Filter Strip Model, VFSMOD v.1.04 (MuñozCarpena and Parsons 2000, 2005), was used to quantify the sediment and water trapping efficiency of a grass filter strip in a cropland setting for a range of buffer area ratios. It is a field-scale, single-event model that is based on the hydraulics of flow and processes of sediment transport and deposition (Muñoz-Carpena et al. 1993, 1999). The front-end UH submodel is empirically based and generates a rainfall hyetograph, a runoff hydrograph, and sediment delivery characteristics to a filter strip using a combination of the USDA Natural Resources Conservation Service curve number method, the unit hydrograph, and the modified Universal Soil Loss Equation (Muñoz-Carpena and Parsons 2004; Suwandono et al. 1999). Retention of sediments and water by the filter strip is simulated by the process-based VFSMOD submodel (Muñoz-Carpena and Parsons 2004). Good agreement between
VFSMOD-modeled and observed trapping efficiencies has been determined for conditions in North Carolina (Muñoz-Carpena et al. 1999), Mississippi (Hayes and Hairston 1983), and Ontario, Canada (Abu-Zreig et al. 2001). The combined model, hereafter referred to as VFSMOD, has undergone testing (Sadeghi et al. 2004) and extensive sensitivity and uncertainty analysis (MuñozCarpena et al. 2007).

The VFSMOD is a one-dimensional flow model, which assumes field runoff enters uniformly along the leading edge of the filter strip. In our application, we held the dimension perpendicular to water flow the same for both the field and the filter strip and changed buffer area ratio by elongating the filter strip. Nonuniform flow, however, converges or diverges, creating many more possible shapes of field and filter areas. Trapping efficiency for any given buffer area ratio may vary with the degree of convergence or divergence that occurs. If variability due to convergence or divergence is low, then the one-dimensional VFSMOD can be used to describe trapping efficiency versus buffer area ratio for nonuniform flow.

Helmers et al. (2005) used a two-dimensional flow model to determine that a large degree of flow convergence can substantially reduce sediment trapping efficiency of a filter strip. A simple analysis of their data further reveals that most of this effect results from the reduced area of filter strip through which converging runoff flows. According to Helmers et al. (2005), sediment trapping efficiency declines by as much as 12 percentage points as flow convergence increases from none (convergence ratio or $\mathrm{CR}=0$ ) to $\mathrm{CR}$ $=0.43$ (illustrated in figure 1) in filter strips of three different lengths (parallel to flow). We replotted these data as sediment trapping efficiency as a function of buffer area ratio (since the field length was $670 \mathrm{~m}[2,198 \mathrm{ft}]$ ) for each level of convergence that they evaluated $(\mathrm{CR}=0,0.22,0.31$, and 0.43). The result shows much closer relationships, less than 3 percentage points, between all four levels of flow convergence (figure 1), indicating that buffer area ratio accounts for most of the effect that flow convergence in a filter strip has on sediment trapping efficiency. Helmers et al. (2005) report further that convergence of runoff in the field has a similar effect on sediment trapping efficiency as convergence within a filter strip. Therefore, the one-dimensional VFSMOD model should provide a reasonably accurate description of the relationship between trapping efficiency and buffer area ratio under nonuniform flow conditions when the modeled area ratio is changed by elongating the filter strip. 
The VFSMOD could be used for site design purposes by repeatedly inputting a different value for filter size, and hence a different buffer area ratio, until the model predicts a desired level of trapping. However, VFSMOD requires detailed input data that may be difficult for a planner to obtain; computers to perform the calculations; and a high level of skill to properly parameterize, run, and interpret the results. In addition, VFSMOD would have to be rerun for every different set of site conditions that are encountered in the field. For designing filter strips, a better model would directly determine the buffer area ratio that would achieve a desired level of trapping and be easier for planners to use for making quick determinations on many and varied sites.

To create a design aid, VFSMOD was simplified in three ways. First, repeated simulations were run to quantify the relationship between trapping efficiency and buffer area ratio for a well-established grass filter strip receiving overland runoff from a crop field under a recommended design storm event. This relationship will enable planners to directly determine a buffer area ratio that will achieve a desired level of trapping efficiency. Simulations included a range of soil textures, slopes, field cover conditions, and rainfall amounts that can significantly affect this relationship (Dosskey 2001; Helmers et al. 2002), and results were obtained for both sediment and water trapping efficiency. Second, the results were displayed graphically. Graphical presentation enables planners to quickly and easily determine a buffer area ratio that will achieve a desired level of trapping efficiency. The VFSMOD results can be used directly for field site conditions that are similar to those conditions that were simulated. Third, simple rules were developed for estimating relationships that VFSMOD would predict for soils, slopes, field cover conditions, rainfall amounts, and pollutant types that were not explicitly simulated in this study. The rules were developed by a visual assessment of the graphed VFSMOD results that show how much a change in one site variable affects the relationship between trapping efficiency and buffer area ratio.

The resulting design aid consists of a single graph (design graph) showing a range of relationships determined by VFSMOD for trapping efficiency as a function of buffer area ratio for a broad suite of site conditions. The relationships shown in the design

\section{Table 1}

Design conditions and assumptions used for conducting all model simulations.

\begin{tabular}{ll}
$\begin{array}{l}\text { Model } \\
\text { component }\end{array}$ & Modeled conditions and assumptions \\
\hline Filter strip & $\begin{array}{l}\text { Well-established grass (25 mm tall, 1.6 mm spacing, Manning's } n=0.40) \\
\text { Slope and soil texture same as the contributing field area } \\
\text { Runoff is uniformly distributed throughout the filter area }\end{array}$ \\
& $\begin{array}{l}\text { Seedbed stage (USLE P factor }=1.0) * \\
\text { Wet antecedent soil moisture }\end{array}$ \\
Field & $\begin{array}{l}\text { Single event } \\
\text { 61 mm in } 1 \text { hour }\end{array}$ \\
Rainfall & $\begin{array}{l}\text { * The USLE P is the support practice factor in the Universal Soil Loss Equation (USLE) } \\
\text { (Wischmeier and Smith 1978). }\end{array}$
\end{tabular}

\section{Table 2}

Values for the four site variables used to evaluate relationships between trapping efficiency for sediment and water and buffer area ratio of filter strips in cultivated agricultural landscapes.

\begin{tabular}{ll}
\hline Variable & Values \\
\hline Slope & $2 \%$ and $10 \%$ \\
Soil texture class & Fine sandy loam and silty clay loam \\
USLE C factor* & 0.15 and 0.50 \\
Field slope length & $200 \mathrm{~m}$ and $400 \mathrm{~m}$ \\
\hline
\end{tabular}

* The USLE C factor is the cover and management factor in the Universal Soil Loss Equation (USLE) (Wischmeier and Smith 1978).

\section{Table 3}

Values for soil parameters used in model simulations that key to soil texture class. Soil hydraulic properties are taken from Rawls et al. (1993).

\begin{tabular}{llllll}
\hline Soil texture class & $\begin{array}{l}\mathbf{K}_{\text {sat }} \\
\left(\mathbf{c m} \mathbf{~ h}^{-\mathbf{1}}\right)\end{array}$ & $\begin{array}{l}\text { Porosity } \\
\left(\mathbf{m}^{\mathbf{3}} \mathbf{~ m}^{-\mathbf{3}}\right)\end{array}$ & $\begin{array}{l}\text { Initial water } \\
\text { content } \\
\left(\mathbf{m}^{\mathbf{3}} \mathbf{~ m}^{-\mathbf{3}}\right)\end{array}$ & $\begin{array}{l}\text { Curve } \\
\text { number }\end{array}$ & $\begin{array}{l}\text { USLE } \\
\mathbf{K} \text { factor } \\
\left(\mathbf{t n}[\mathbf{a c ~ E I}]^{-\mathbf{1}}\right)^{*}\end{array}$ \\
\hline Silty clay loam & 0.20 & 0.471 & 0.169 & 90 & 0.37 \\
Fine sandy loam & 2.18 & 0.453 & 0.064 & 75 & 0.20 \\
\hline
\end{tabular}

* The USLE $\mathrm{K}$ factor is the soil erodibility factor in the Universal Soil Loss Equation (USLE) (Wischmeier and Smith 1978).

graph can be used directly for design where field site conditions are similar to those represented by one of the lines in the design graph. For a site that differs significantly from conditions represented by the lines shown in the design graph, simple rules are presented for quickly determining which of these lines would represent a reasonable approximation of what VFSMOD would predict for that set of conditions.

Model Simulations. For all simulations, runoff was generated by a rainfall event of 61 $\mathrm{mm}$ (2.4 in) in 1 hour onto a wet, cultivated field (table 1). This size of rainfall event has a 10-year return frequency across the Central Plains (e.g., Garden City, Kansas), Corn Belt (e.g., Ames, Iowa), and northern Piedmont (e.g., Durham, North Carolina) regions (Herschfield 1961). A 10-year return-frequency is often recommended for designing conservation practices (Haan et al. 1994; Larson et al. 1997). Field runoff was delivered uniformly to a well-established grass filter strip having the same slope and soil texture as the cultivated field.Values for specific modeling parameters that describe these simulation conditions are shown in table 1.

Four site variables were evaluated: slope, soil texture, field slope length, and field cover management practice (i.e., Universal Soil Loss Equation [USLE] C factor) (Wischmeier and Smith 1978). Slope and soil texture affect 
the trapping capability of a filter strip, and when coupled with field size and cover management, they largely determine the input load of runoff water and sediment to the filter strip (e.g., Phillips 1989; Helmers et al. 2002). For the simulations, two values were selected for each variable that bracket a wide range of agricultural site conditions (table 2). The high value for $\mathrm{C}$ factor $(0.50)$ generally describes the seedbed stage of corn after corn or grain sorghum using disk plow tillage or corn after beans using chisel tillage (Wischmeier and Smith 1978). The low value for $\mathrm{C}$ factor $(0.15)$ generally describes corn after corn with chisel or no-tillage that leaves good residue cover. Values for parameters used in VFSMOD that are keyed to soil texture class are listed in table 3.

Simulations were conducted for ten different combinations of values for the four site variables. For each combination, simulations were repeated for several filter strip lengths (parallel to flow): 4, 12, 20, and $30 \mathrm{~m}$ (13.1, 39.4, 65.6, and $98.4 \mathrm{ft})$ when field slope length was selected to be $200 \mathrm{~m}$ (656 ft), and 8, 24, 40, and $60 \mathrm{~m}(26.2,78.7,131$, and 197 $\mathrm{ft}$ ) when field slope length was selected to be $400 \mathrm{~m}(1,312 \mathrm{ft})$, providing buffer area ratios of $0.02,0.06,0.10$, and 0.15 for each field length. From the output data of each simulation, trapping efficiency was determined for sediment and for water. Trapping efficiency was calculated as the difference between the input load to the filter strip and the output load as a percentage of the input load. The results were plotted to illustrate the range of possible relationships between trapping efficiency and buffer area ratio among different site conditions and runoff materials (sediment and water) and to visually gauge how much the relationship is affected by a substantial change in one or more of these variables.

\section{Results and Discussion}

Simulation Results. The simulation results clearly show that trapping efficiency increases as the buffer area ratio increases (figure 2). However, the buffer area ratio that is required to yield a given level of trapping efficiency is extremely variable. A ratio as low as 0.02 was estimated to trap nearly $100 \%$ of the incoming material in one case, while a ratio of 0.15 trapped only $11 \%$ of the load in another case. The trapping efficiency for a given buffer area ratio depends very strongly on the kind of material being trapped. High trapping efficiencies were estimated for sedi-

\section{Figure 2}

Contrast between sediment and water on the relationship between trapping efficiency and buffer area ratio for two different site conditions: Condition A (fine sandy loam, Universal Soil Loss Equation variable for field cover [C factor] $=0.50$, field length $=200 \mathrm{~m}$, slope $=2 \%$ ) and Condition B (silty clay loam, C factor $=0.15$, field length $=200 \mathrm{~m}$, slope $=2 \%$ ).

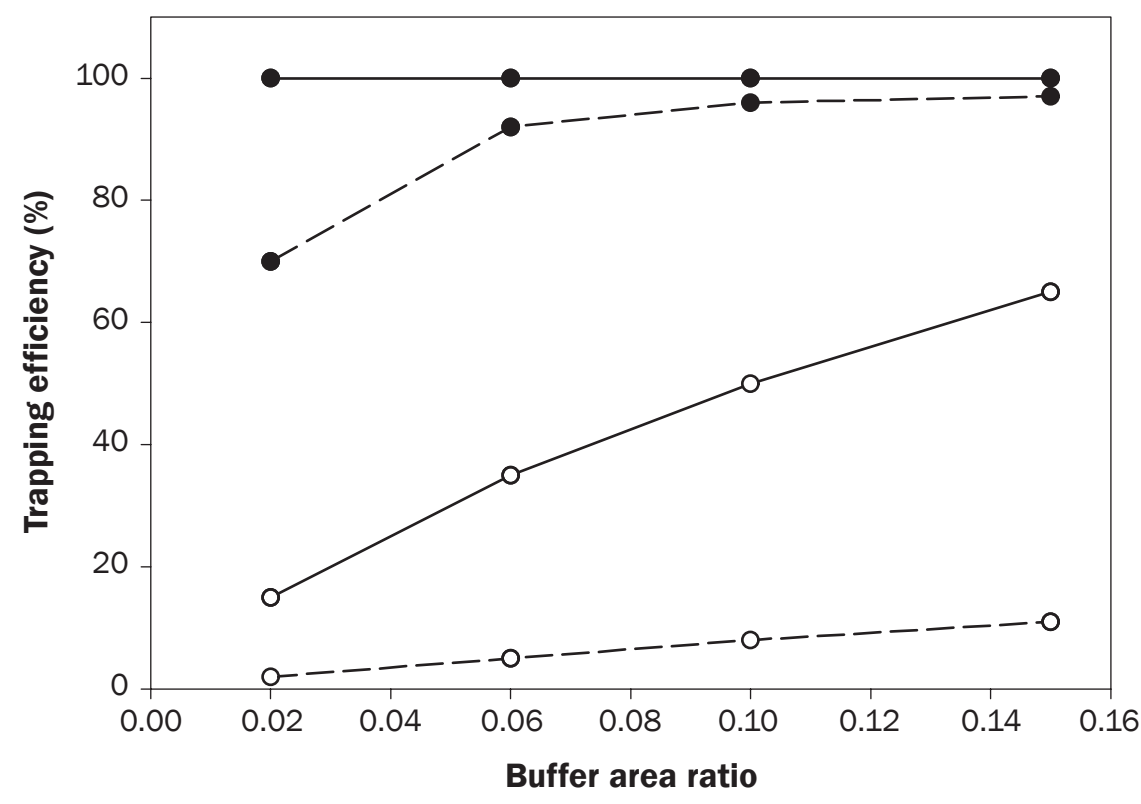

Legend

$\longrightarrow$ Condition A, sediment

O_ C Condition A, water

- - Condition B, sediment

O- - - O Condition B, water

ment, and much lower trapping efficiencies were estimated for water under the same site conditions. The low trapping efficiencies for water illustrate that rainfall plus field runoff often greatly exceeds the infiltration capacity of filter strips. Site conditions also influence the relationship between trapping efficiency and buffer area ratio. For example, a filter strip on coarse-textured soil below a diskplowed corn field $(\mathrm{C}$ factor $=0.50)$ yielded substantially higher trapping efficiencies for sediment and water than an otherwise similar strip on fine-textured soil below a chiseltilled corn field $(\mathrm{C}$ factor $=0.15)$ (figure 2$)$. Overall, these results illustrate that in some situations, relatively small filter areas can have a high impact, while in others, even a modest impact cannot be achieved at any practical buffer area ratio.

The site variables soil texture and slope had substantial effects on the relationship between trapping efficiency and buffer area ratio of a filter strip. A filter strip on a steeper slope exhibits lower trapping efficiency for a given buffer area ratio than one on a flatter slope (figure 3). A filter strip on a finer-textured soil (e.g., silty clay loam) exhibits lower trapping efficiency than one on a coarser textured soil (e.g., fine sandy loam). For example, a ratio of 0.10 would trap $100 \%$ of incoming sediment on a $2 \%$ slope consisting of fine sandy loam soil, while the same filter strip would trap only $21 \%$ of incoming sediment on a $10 \%$ slope consisting of silty clay loam soil. Each of these two site characteristics can have large individual effects. For example, a 0.02 ratio on a $2 \%$ slope of fine sandy loam soil would trap nearly $100 \%$ of sediment in runoff but only 35\% of runoff sediment if the soil was silty clay loam. The finer-textured soil experiences less infiltration in the field and in the filter strip and produces more fine particles that are less easily deposited in a filter strip. The slope effect is also large. For example, a 0.10 ratio on a silty clay loam having a $2 \%$ slope would trap $85 \%$ of incoming sediment but only $20 \%$ of incoming sediment if the slope was $10 \%$. Greater slope and finer-textured soil act to both increase field runoff load and reduce the trapping capability of a filter strip, which explains the large effect that each of these variables has on trapping efficiency. 
Site characteristics that affect only the field runoff load had a smaller effect on the relationship between trapping efficiency and buffer area ratio. Poorer cover management (higher $\mathrm{C}$ factor), which produces greater runoff loads, yielded lower sediment trapping efficiency for a given buffer area ratio than better cover management (figure 4). The corresponding effect on water trapping efficiency was negligible. While the C factor had a marked effect on sediment trapping efficiency, it was not as large as the individual effects of slope and soil texture displayed in figure 3. Overall, the simulation results illustrate the importance of both runoff load and filter capability in quantifying the relationship between trapping efficiency and buffer area ratio of filter strips.

A doubling of field slope length from 200 to $400 \mathrm{~m}$ (656 to $1,312 \mathrm{ft}$ ) did not substantially affect the relationship between trapping efficiency and buffer area ratio in most cases. For 9 of 10 different combinations of slope, soil texture, field cover management, and material type (sediment and water), elongating the field slope two-fold reduced trapping efficiency by less than 3 percentage points for a given buffer area ratio (e.g., Conditions $\mathrm{A}, \mathrm{B}$, and $\mathrm{D}$ in figure 5 ). In one scenario, however, elongating the slope reduced trapping efficiency for water by almost 10 percentage points (Conditions $\mathrm{C}$ in figure 5 ). Collectively, these results are consistent with those of our analysis of the Helmers et al. (2005) data showing that varying the shape of the runoff area has only a small effect on the relationship between trapping efficiency and buffer area ratio. The present results also indicate, however, that specific circumstances may be occasionally encountered under which a shape effect could be significant.

Design Aid Development. From the collection of simulation results, seven relationships were selected that span the range of results in fairly equal increments. Nonlinear regression of the equation form

$y=a\left(1-e^{-b x}\right)$

where $y$ is trapping efficiency in percent and $x$ is buffer area ratio, was conducted on the data points from each of the selected sets of simulation conditions (table 4), and the regressed relationships were plotted (figure 6). Other equation forms were evaluated, but this one produced a near-perfect fit for all seven relationships (table 5).

\section{Figure 3}

Contrast between different soils (fine sandy loam and silty clay loam) and slopes ( $2 \%$ and $10 \%$ ) on sediment trapping efficiency as a function of buffer area ratio. All four of these simulations have field slope length of $\mathbf{2 0 0} \mathrm{m}$ and a Universal Soil Loss Equation variable for field cover (C factor) of 0.50 . Lack of data points for narrower widths in the simulation of fine sandy loam on $10 \%$ slope is due to sediment deposition filling the narrow filter strip to capacity before the runoff event ended.

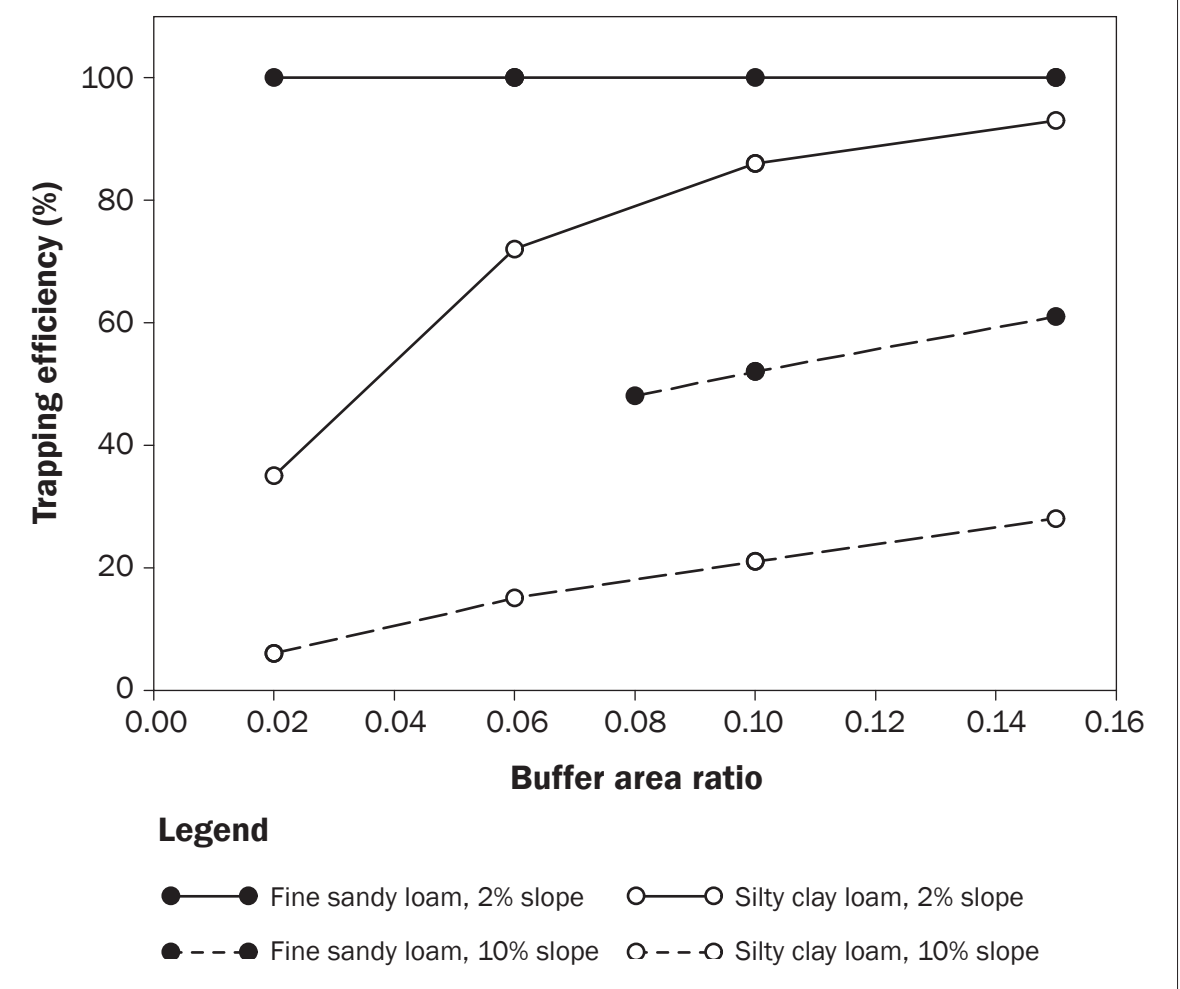

The relationships that are illustrated in figure 6 can be used as a design aid for determining appropriate size for filter strips. First, identify one line in the graph that represents conditions that are most similar to the actual site using table 4 . Then, use that line to read the corresponding buffer area ratio that will achieve a desired level of trapping efficiency. Multiplying this ratio by the size of the field area that contributes runoff to a given location along a field margin will indicate the size of filter area needed at that location. The area of field that contributes runoff to each segment of the field margin can be visually estimated in the field by observing indicators, such as topography and patterns of tillage, rills, and sediment and residue deposits after rainfall events, as described in Dosskey et al. (2002) or determined remotely by using topographic maps as described by Bren (1998) and Dosskey et al. (2005).

The line selection process is the key to obtaining a reasonable estimate for size of a filter area. It is straightforward for a site that has similar conditions to one of those that is plotted in figure 6. In most cases, however, actual site conditions will differ from these simulations in one or more variables. In such cases, selecting the best line will require two steps. First, pick a reference line to start from, such as one for which simulation conditions are more similar to the actual site. Then, adjust to a different line based on how much the actual site conditions differ from those that represent the initial reference line. In general, adjust to a line above the reference line for conditions that would yield a smaller runoff load or greater filter capability than the reference conditions, and to a line below the reference line for conditions that would yield greater runoff load or less filter capability than the reference conditions.

Rules of thumb were developed for determining how many lines above or below the initial reference line would be most appropriate for a given site (table 6). These adjustment rules were gauged from the graphed simulation results showing how much the relationship differed between two values of each variable (slope, soil texture, $\mathrm{C}$ factor, mate- 


\section{Figure 4}

Contrast between different values of field Universal Soil Loss Equation variable for field cover (C factor) ( 0.15 and 0.50 ) on trapping efficiency as a function of buffer area ratio. All simulations have $2 \%$ slope on silty clay loam soil.

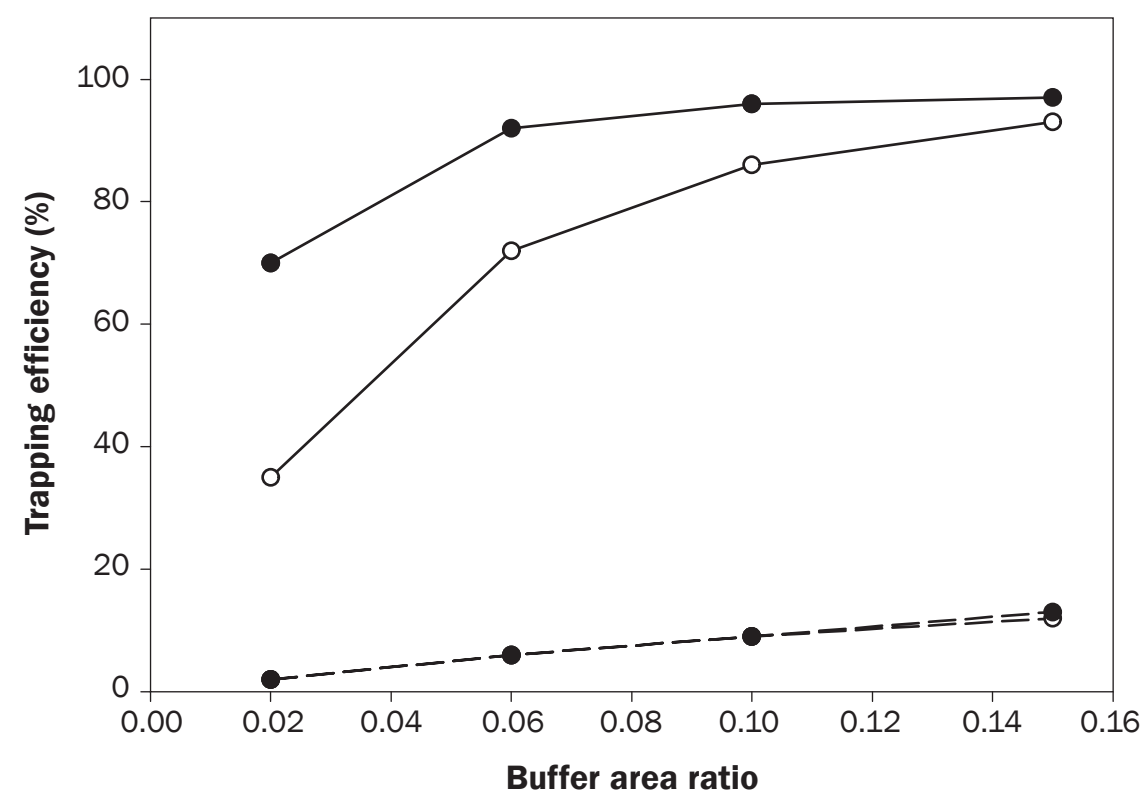

Legend

$\longrightarrow$ Sediment, $\mathrm{C}$ factor $=0.15$

○ S Sediment, $\mathrm{C}$ factor $=0.50$

- Water, $\mathrm{C}$ factor $=0.15$

O- - - o Water, C factor $=0.50$

\section{Table 4}

Simulation conditions corresponding to each line in figure 6.

\begin{tabular}{llllll}
\hline $\begin{array}{l}\text { Line } \\
\text { number }\end{array}$ & $\begin{array}{l}\text { Material } \\
\text { type }\end{array}$ & $\begin{array}{l}\text { Slope } \\
\mathbf{( \% )}\end{array}$ & $\begin{array}{l}\text { Soil } \\
\text { texture } \\
\text { class }\end{array}$ & $\begin{array}{l}\text { USLE C } \\
\text { factor* }\end{array}$ & $\begin{array}{l}\text { Field } \\
\text { length }(\mathbf{m})\end{array}$ \\
\hline 7 & Sediment & 2 & $\mathrm{FSL}$ & 0.50 & 200 \\
6 & Sediment & 2 & $\mathrm{SiCL}$ & 0.15 & 200 \\
5 & Sediment & 2 & $\mathrm{SiCL}$ & 0.50 & 200 \\
4 & Water & 2 & $\mathrm{FSL}$ & 0.50 & 400 \\
3 & Water & 10 & $\mathrm{FSL}$ & 0.50 & 200 \\
2 & Sediment & 10 & $\mathrm{SiCL}$ & 0.50 & 200 \\
1 & Water & 10 & $\mathrm{SiCL}$ & 0.50 & 200 \\
\hline Notes: FSL = fine sandy loam. SiCL $=$ silty clay loam. & & \\
* The USLE C factor is the cover and management factor in the Universal Soil Loss Equation \\
(USLE) (Wischmeier and Smith 1978).
\end{tabular}

rial type). That amount of difference between relationships was expressed in terms of distance between lines shown in figure 6. For example, the difference between a site having a $2 \%$ slope and one having a $10 \%$ slope (all other variables being equal) can be estimated from figure 3 to be approximately three lines, or about one line for each $2.5 \%$ difference in slope ( $8 \%$ divide by three lines). In this way, adjustment rules were line lower than a sediment reference line may be used to describe sediment-bound pollutants. Retention of sediment-bound pollutants is somewhat less than for sediment as a whole since they tend to be associated more with finer particles, such as clays and fine silts, which do not deposit as readily in filter strips as sands and coarse silts (Lee et al. 2000; Schmitt et al. 1999). For example, phosphorus $(\mathrm{P})$ in runoff from tilled fields is mainly sediment-bound, and field plot studies have shown that total $\mathrm{P}$ retention is about 10 percentage points less than for sediment (Dillaha et al. 1989; Schmitt et al. 1999). Three broad soil texture categories (coarse, medium, and fine) are recognized based on our judgment of the balance between particle-size distribution, erodiblity, and water permeability. Estimates of values for $\mathrm{C}$ factor for various cultivation systems can be obtained from look-up tables in Wischmeier and Smith (1978) and publications of state USDA Natural Resources Conservation Service offices, university extension services (e.g., NCES 1988), or by estimation using USDA Web-based software (USDA 2007).

The adjustment rules for water include selecting one line above or below a water reference line for each $7.5 \%$ lesser or steeper slope, respectively, and each soil texture category coarser or finer, respectively (table 6). Simulation results for water indicate that no significant adjustment is needed for C factor (e.g., figure 4). Since infiltration of runoff water is the main process by which its solute content is retained, retention of dissolved pollutants such as nitrate, atrazine, and dissolved phosphorus may be approximated by the line for water. Plot studies show that water infiltration in filter strips can underestimate dissolved pollutant retention by up to 16 percentage points for a single, independent runoff event (Schmitt et al. 1999). However, this underestimate can be offset where previously trapped solutes are remobilized into overland flow during subsequent runoff events (Dillaha et al. 1989; Lee et al. 2000). Since some remobilization will probably occur in typical applications, net retention of dissolved pollutants is probably similar enough to water for the purposes of this design aid.

An example of the process for selecting an appropriate line from figure 6 is illustrated in the worksheet in table 7 . For the field site conditions shown in this table, line number five was identified as the initial ref- 
erence, and adjustment was necessary for substantial departures in slope, soil texture, and pollutant type. Using the rules of thumb for sediment and sediment-bound pollutants listed in table 6 , a net adjustment of one line below the initial reference line was indicated, so line number four was determined to be most appropriate for describing total $\mathrm{P}$ trapping under the conditions at that field site. If the worksheet produces a final line number higher than seven or lower than one, then line seven or line one, respectively, should be used as the design line.

Accuracy of the Adjustment Rules. The accuracy of the adjustment rules was evaluated by determining how consistently the rules identified the proper VFSMOD-predicted line for a given simulation condition by starting from a different simulation condition (reference line) and making adjustments for differences in site conditions according to the adjustment rules. This test assesses rules for the individual site variables as well as the use of them in combination. A matrix containing those results on conditions for the lines in figure 6 (table 4) shows that the adjustment rules identified the proper VFSMOD-predicted line in all 18 possible cases (table 8).

Accuracy of the adjustment rules was also tested in a similar manner on the remaining sets of conditions that are not displayed in figure 6 . Three additional simulation conditions were tested that were generated in a previous study (Dosskey et al. 2002). For this latter group, design aid-selected lines were compared to corresponding lines that were generated by VFSMOD specifically for each of those site conditions. Average conditions among these three study sites ranged from silty clay loam to silt loam and $2 \%$ to $4 \%$ slope, and all had a C factor of 0.50 (Dosskey et al. 2002). Adjustments for field site conditions were interpolated to the nearest half line for differences in conditions that were between the increments specified in table 6 . For the five sediment simulations, the design aid-selected lines were within one-half line of site-specific VFSMOD simulations (figure 7). Accuracy of the design aid-selected lines for water trapping was somewhat lower, within one line of the site-specificVFSMOD simulations. The design aid showed no strong bias toward overestimating or underestimating the VFSMOD-predicted relationship. However, the design aid is less precise than the full VFSMOD model because of the

\section{Figure 5}

Contrast between 200 and $400 \mathrm{~m}$ field length on the relationship between trapping efficiency and buffer area ratio for four different conditions. Condition A (sediment, silty clay loam, slope $=\mathbf{2} \%$, Universal Soil Loss Equation variable for field cover [C factor] $=0.15$ ), Condition B (sediment, silty clay loam, slope $=2 \%, C$ factor $=0.50$ ), Condition C (water, fine sandy loam, slope $=$ $2 \%, C$ factor $=0.50$ ), and Condition D (water, silty clay loam, slope $=2 \%, C$ factor $=0.50$ ).

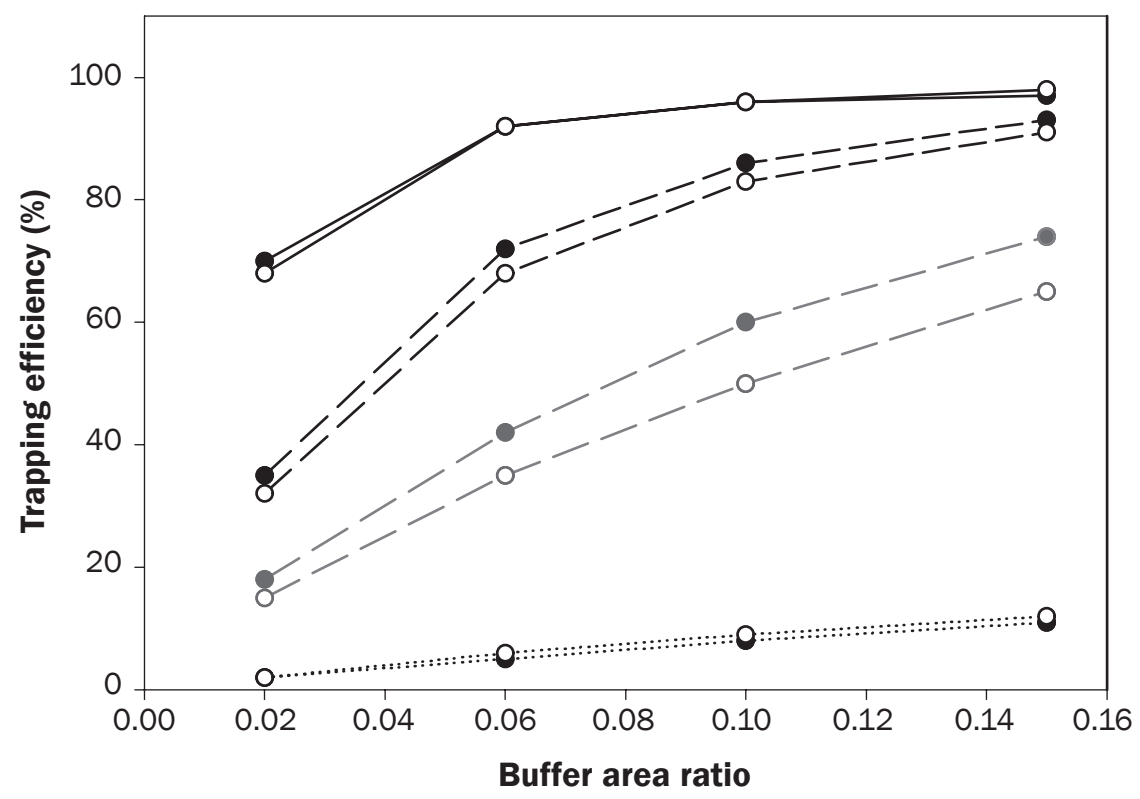

Legend

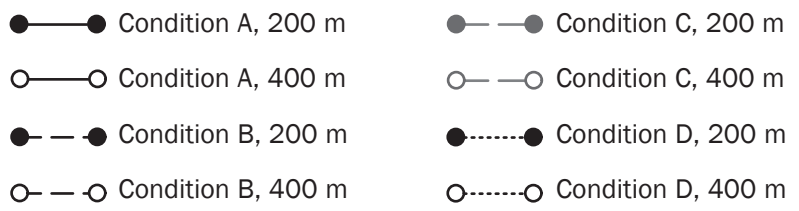

Table 5

Regression equations and fit statistics for the seven reference lines that are shown in figure 6.

\begin{tabular}{llll}
\hline \multirow{2}{*}{ Line number } & \multicolumn{3}{l}{ Equation $\boldsymbol{y}=\mathbf{a}\left(\mathbf{1}-\mathbf{e}^{-b \boldsymbol{x}}\right)$} \\
\cline { 2 - 4 } $\boldsymbol{a}$ & $\boldsymbol{b}$ & Adjusted $\boldsymbol{r}^{\mathbf{2}}$ \\
\hline 7 & 100 & + infinity & 1.0000 \\
6 & 95.82 & 64.80 & 0.9997 \\
5 & 96.23 & 22.66 & 1.0000 \\
4 & 95.01 & 9.99 & 0.9997 \\
3 & 78.77 & 6.69 & 0.9998 \\
2 & 41.85 & 7.25 & 0.9992 \\
1 & 17.52 & 4.85 & 0.9947
\end{tabular}

simplifications made in translating it into a design aid.

Planners that have a deeper knowledge of agricultural runoff and filter strip processes may want to make finer adjustments than those listed in table 6. Interpolation between lines for differences in conditions that do not closely match the increments listed in table 6 might lead to better line selection from figure 6 , such as was done in the latter test of the adjustment rules. Also, adjustment may be desired for additional variables or departures from design aid assumptions that are known to affect runoff load or filtering capacity. If they significantly decrease field runoff load and/or increase filter capability, an additional 


\section{Figure 6}

Relationships between pollutant trapping efficiency and buffer area ratio for seven different site conditions from among the full set of conditions that were simulated in this study. The specific conditions represented by each line are listed in table 4 .

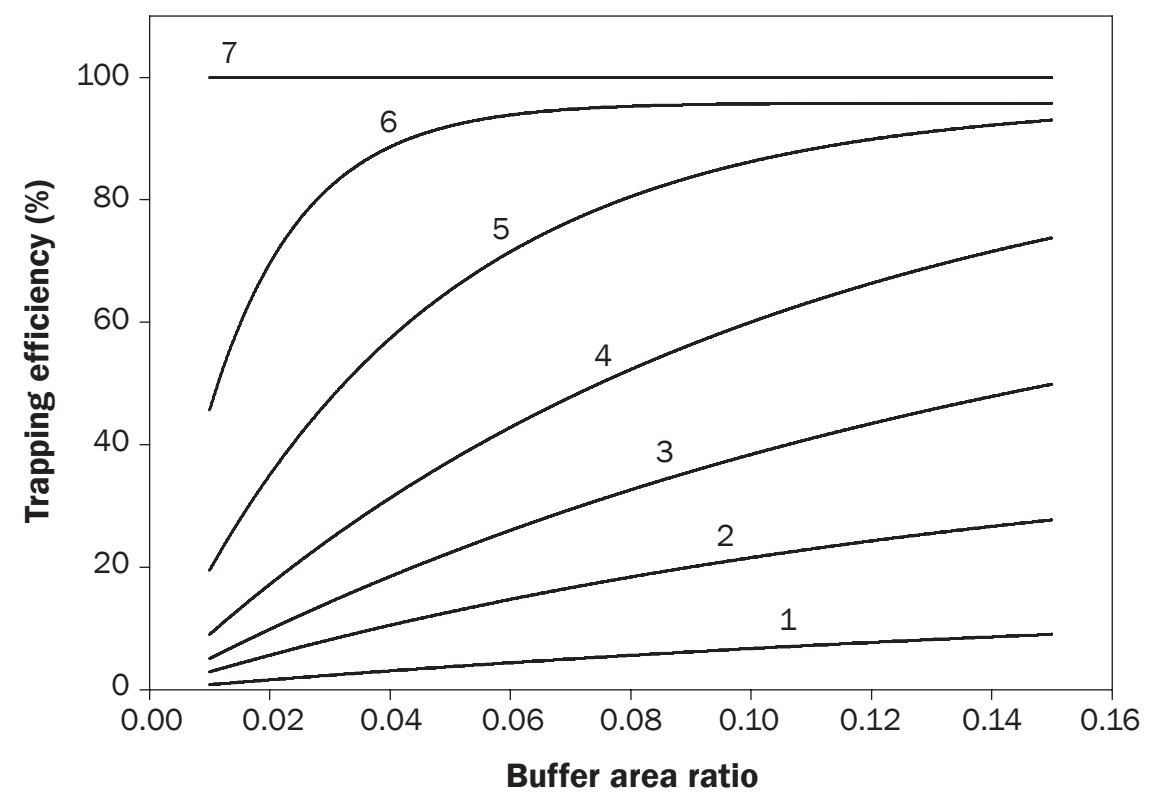

\section{Table 6}

Rules for adjusting from an initial reference line in figure 6 to a final selected line based on how much the actual field site conditions differ from the reference simulation conditions. Different rules are used depending on the pollutant type: sediments and sediment-bound pollutants or dissolved pollutants and water. For soil texture, three broad categories are recognized: coarse (sandy loam, sandy clay loam, fine sandy loam), medium (very fine sandy loam, loam, and silt loam), and fine (clay loam, silty clay loam, silt).

\begin{tabular}{ll}
\hline Variable & Adjustment rule \\
\hline Sediment and sediment-bound pollutants & 1 line lower $(-1)$ from sediment to sediment-bound \\
\hline Pollutant type & $\begin{array}{l}1 \text { line higher }(+1) \text { for each } 2.5 \% \text { lesser slope } \\
1 \text { line lower }(-1) \text { for each } 2.5 \% \text { greater slope }\end{array}$ \\
Slope & $\begin{array}{l}1 \text { line higher }(+1) \text { for each category coarser } \\
1 \text { line lower }(-1) \text { for each category finer }\end{array}$ \\
Soil texture & 1 line higher $(+1)$ for each 0.35 lower $C$ factor \\
& 1 line lower $(-1)$ for each 0.35 higher C factor
\end{tabular}

Dissolved pollutants and water

Pollutant type No adjustment between dissolved pollutants and water

Slope $\quad 1$ line higher $(+1)$ for each $7.5 \%$ lesser slope

1 line lower (-1) for each $7.5 \%$ greater slope

Soil texture

1 line higher (+1) for each category coarser

1 line lower $(-1)$ for each category finer

USLE C factor*

No adjustment

* The USLE C factor is the cover and management factor in the Universal Soil Loss Equation (USLE) (Wischmeier and Smith 1978). adjustment to a higher line might be appropriate and visa versa. For example, if a planner prefers to design for a significantly smaller storm event, such as $41 \mathrm{~mm}$ (1.6 in) instead of $61 \mathrm{~mm}$ (2.4 in), then an adjustment to a higher line would be appropriate (figure 8). Enabling interpolations and adjustments for additional site factors and design conditions broadens the range of planning circumstances to which this design aid can be applied.

Application of the Design Aid. This design aid provides a quantitative method for designing filter strips where runoff flow from cultivated fields is nonuniform. It enables a planner to design a filter strip that varies in size between segments of field margin where field runoff converges or diverges, thereby providing a known and constant level of trapping efficiency along an entire field margin. This method extends the design procedure of Bren (1998) by enabling a planner to select and quantify the level of trapping efficiency to be achieved.

Currently, filter strips (Code 393) are designed for uniform runoff flow conditions (USDA 1997), and the procedure of Dosskey et al. (2008) can be used to determine filter strip size for that condition. Where runoff flow is nonuniform, the standards call for establishing uniform runoff prior to installation. Practices such as land shaping and level spreaders are ways to establish uniform runoff flow, but they add substantial effort and cost to creating effective filter strips. Alternatively, use of this present design aid may reduce or eliminate the need for establishing uniform runoff flow by simply placing more filter area where runoff load is greater and less filter area where runoff load is smaller.

There are four important limitations for the use of this design aid that stem from the VFSMOD model on which it is based. First, the VFSMOD model describes only infiltration limited, or Hortonian, overland flow processes. Therefore, the design aid may not produce accurate results for sites having a shallow impermeable layer that would cause the overlying soil to saturate and restrict further infiltration during a rainfall event. Second, the UH submodel in VFSMOD assumes that sediment load is generated only by sheet and rill erosion, and in our simulations, the filter strip vegetation was not overtopped by runoff flow. If convergent flow would cause gullying and overtopping conditions to occur, it must be 
mitigated before this design aid can produce reliable results. Practices that are used for treating convergent, or concentrated, flows include vegetative barriers (Code 601) and grassed waterways (Code 412). Third, our VFSMOD simulations do not account for the effect of sediment buildup on filter strip functioning during subsequent events. Filter strips that trap sediment will fill with sediment sooner or later and stop functioning properly. Procedures have been developed to estimate the functioning life span of filter strips based on filter strip size, field runoff load, and trapping efficiency (Dillaha and Hayes 1991). Eventually, sediment must be removed in order to maintain proper flow conditions and trapping efficiencies that are estimated by VFSMOD and this design aid. Fourth, VFSMOD does not account for subsequent movement of pollutants that infiltrate in a filter strip. Infiltration may simply divert some dissolved substances like nitrate to a groundwater path toward water bodies. Other practices, such as riparian forest buffers (Code 391), are recommended for treating pollutants in shallow subsurface and groundwater flow and should be combined with filter strips where pollutant movement after infiltration could be a problem.

\section{Summary and Conclusions}

The process-basedVFSMOD model, including the empirically based upland component $(\mathrm{UH})$, was used to evaluate relationships between pollutant trapping efficiency of a filter strip and the ratio of filter strip area to contributing area (i.e., buffer area ratio). Simulation results clearly show that trapping efficiency for sediment and water increase nonlinearly as the buffer area ratio gets larger. However, the buffer area ratio required to yield a given level of trapping efficiency varies substantially with pollutant type, slope, soil texture, and field C factor. In general, a greater ratio is required for dissolved pollutants (compared to sediment), steeper slopes, finer soil textures, and higher $\mathrm{C}$ factors.

The simulation results were used to develop a design aid for filter strips based on buffer area ratio that can be used where nonuniform runoff occurs. A graphical design aid was produced that enables planners to determine appropriate design ratios for filter strips that can achieve desired trapping efficiencies for a broad range of agricultural site conditions and pollutant types. It is easy to use, accounts for several major variables

\section{Figure 7}

Frequency distribution for the number of lines that the design-aid underestimated (-) or overestimated (+) the Vegetative Filter Strip Model-predicted relationship between trapping efficiency and area ratio for simulation conditions in this study not shown in table 8 and for three additional simulations published in Dosskey et al. (2002). Each symbol represents one comparison.

Water

0

000

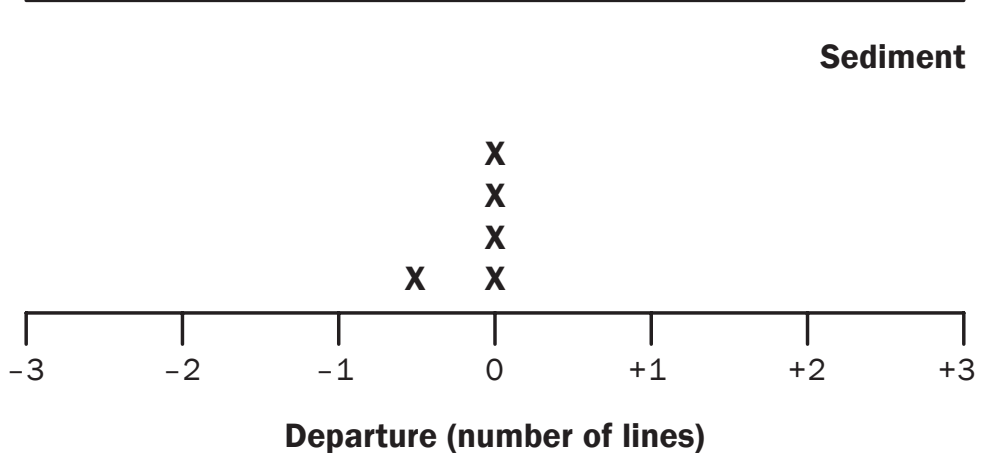

Table 7

Example of the two-step line selection process. In this case, line number five in figure 6 was identified as the initial reference line, and after applying the adjustment rules in table 6 , line four was selected as the best relationship to use for filter strip design on this site.

\begin{tabular}{lllll}
\hline Variable & $\begin{array}{l}\text { Initial } \\
\text { reference } \\
\text { line }\end{array}$ & $\begin{array}{l}\text { Field } \\
\text { site } \\
\text { condition }\end{array}$ & $\begin{array}{l}\text { Adjustment } \\
\text { rule }\end{array}$ & $\begin{array}{l}\text { Final } \\
\text { selected } \\
\text { line }\end{array}$ \\
\hline Slope & $2 \%$ & Loam & -1 & +1 \\
Soil texture & $\mathrm{SiCL}$ & 0.50 & 0 & \\
USLE C factor* & 0.50 & Total phosphorus & -1 & \\
Pollutant type & Sediment & & Total adjustments & Line number \\
\hline & Line number & & -1 & 4 \\
\hline
\end{tabular}

Note: $\mathrm{SiCL}=$ silty clay loam.

* The USLE C factor is the cover and management factor in the Universal Soil Loss Equation (USLE) (Wischmeier and Smith 1978).

that determine filter strip performance, and is based on a validated filter strip model. The use of this design aid will enable a more precise fit between filter size and runoff load where runoff from agricultural fields is nonuniform.

\section{Acknowledgements}

Financial assistance for this project was provided in part by the USDA Forest Service National Agroforestry Center; USDA Cooperative State Research, Education, and Extension Service Integrated Research, Education, and Extension Competitive Grants Program; Nebraska Corn Growers Association; and the USDA National Needs Fellowship Program. This paper is a contribution of the University of Nebraska Agricultural Research Division supported in part by funds provided through the Hatch Act.

\section{References}

Abu-Zreig, M., R.P. Rudra, and H.R. Whiteclay. 2001 Validation of a vegetated filter strip model (VFSMOD). Hydrological Processes 15:729-742.

Bren, L.J. 1998. The geometry of a constant buffer-loading design method for humid watersheds. Forest Ecology and Management 110:113-125.

Bren, L.J. 2000. A case study in the use of threshold measures of hydraulic loading in the design of stream buffer strips. Forest Ecology and Management 132:243-257.

Daniels, R.B., and J.W. Gilliam. 1996. Sediment and chemical load reduction by grass and riparian filters. Soil Science Society of America Journal 60:246-251.

Dickey, E.C., and D.H. Vanderholm. 1981. Vegetative filter treatment of livestock feedlot runoff. Journal of Environmental Quality 10:279-284. 


\section{Figure 8}

Contrast between rainfall amounts ( 41 and $61 \mathrm{~mm}$ rainfall in 1 hour) on the relationship between sediment trapping efficiency and buffer area ratio for two different site conditions: Condition A (silty clay loam, Universal Soil Loss Equation variable for field cover [C factor] $=0.5$, field length $=\mathbf{2 0 0} \mathrm{m}$, slope $=\mathbf{2} \%$ ) and Condition B (silty clay loam, C factor $=0.5$, field length $=\mathbf{2 0 0}$ $\mathrm{m}$, slope $=10 \%$ ). Data for the corresponding $41 \mathrm{~mm}$ rainfall events are from model simulations presented in Helmers et al. (2002).

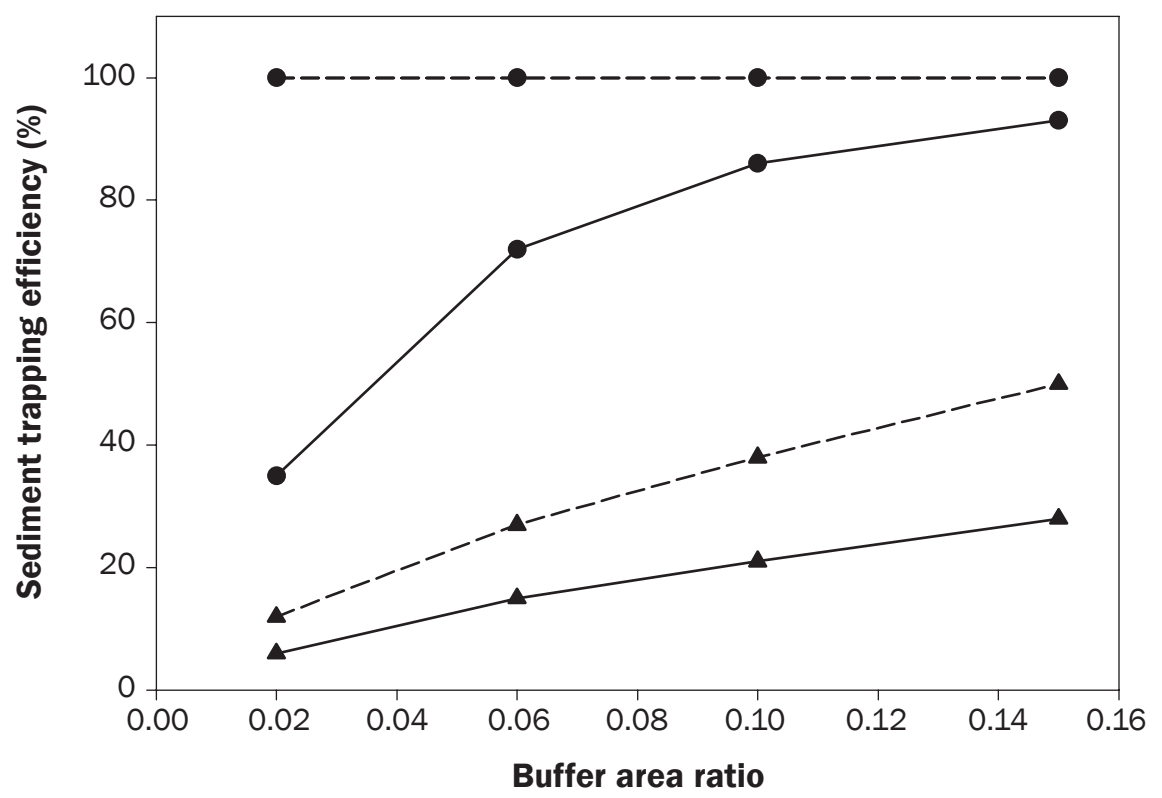

Legend

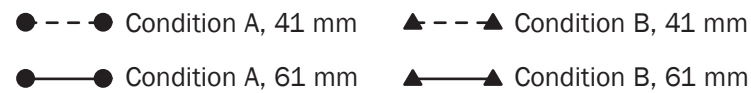

\section{Table 8}

Matrix of results for a test of accuracy and consistency of the adjustment rules. Each line in figure 6 was selected as the initial reference line, and then the adjustment rules (table 6) were applied for conditions that differed between it and every other line representing that pollutant type (table 4) to determine how closely the final selected line number (body of the table) matched the Vegetative Filter Strip Model-generated line number for those specific conditions (left-hand column).

\begin{tabular}{llllllll}
\hline \multirow{2}{*}{$\begin{array}{l}\text { Conditions } \\
\text { line number }\end{array}$} & \multicolumn{7}{l}{ Reference line number } \\
\cline { 2 - 7 } & $\mathbf{7}$ & $\mathbf{6}$ & $\mathbf{5}$ & $\mathbf{4}$ & $\mathbf{3}$ & $\mathbf{2}$ & $\mathbf{1}$ \\
\hline 7 & - & 7 & 7 & - & - & 7 & - \\
6 & 6 & - & 6 & - & - & 6 & - \\
5 & 5 & 5 & - & - & - & 5 & - \\
4 & - & - & - & - & 4 & - & 4 \\
3 & - & - & - & 3 & - & - & 3 \\
2 & 2 & 2 & 2 & - & - & - & - \\
1 & - & - & - & 1 & 1 & - & - \\
\hline Note: $-=$ not applicable. & & & & & &
\end{tabular}

Dillaha, T.A., and J.C. Hayes. 1991. A Procedure for the Design of Vegetative Filter Strips. Final Report to the Soil Conservation Service. Washington DC: USDA.

Dillaha, T.A., R.B. Reneau, S. Mostaghimi, and D. Lee. 1989. Vegetative filter strips for agricultural nonpoint source pollution control. Transactions of the American Society of Agricultural Engineers 32:513-519.

Dillaha, T.A., J.H. Sherrard, and D. Lee. 1986. Long-term effectiveness and maintenance of vegetative filter strips. Bulletin 153,Virginia Water Resources Research Center, Virginia Polytechnic Institute and State University, Blacksburg,VA.

Dillaha, T.A., J.H. Sherrard, D. Lee, S. Mostaghimi, and V.O. Shanholz. 1988. Evaluation of vegetative filter strips as a best management practice for feed lots. Journal of the American Water Pollution Control Federation 60:1231-1238.

Dosskey, M.G. 2001. Toward quantifying water pollution abatement in response to installing buffers on crop land. Environmental Management 28:577-598.

Dosskey, M.G., D.E. Eisenhauer, and M.J. Helmers. 2005. Establishing conservation buffers using precision information. Journal of Soil and Water Conservation 60(6):349-354.

Dosskey, M.G., M.J. Helmers, D.E. Eisenhauer. 2008. A design aid for determining width of filter strips. Journal of Soil and Water Conservation 63(4):232-241, doi:10.2489/jswc.63.4.232.

Dosskey, M.G., M.J. Helmers, D.E. Eisenhauer, T.G. Franti, and K.D. Hoagland. 2002. Assessment of concentrated flow through riparian buffers. Journal of Soil and Water Conservation 57(6):336-343.

Fabis, J., M. Bach, and H.-G. Frede. 1993. Vegetative filter strips in hilly areas of Germany. In Integrated Resource Management \& Landscape Modification for Environmental Protection, ed. J.K. Mitchell, 81-88. Proceedings of the International Symposium, Dec. 13, 1993, Chicago, IL. St. Joseph, MI: American Society of Agricultural Engineers.

Haan, C.T., B.J. Barfield, and J.C. Hayes. 1994. Design Hydrology and Sedimentology for Small Catchments. New York: Academic Press.

Hayes, J.C., and J.E. Hairston. 1983. Modeling Long-term Effectiveness of Vegetative Filters as On-site Sediment Controls. Paper No. 83-2081. St. Joseph, MI: American Society of Agricultural Engineers.

Helmers, M.J., D.E. Eisenhauer, M.G. Dosskey, and T.G. Franti. 2002. Modeling Vegetative Filter Performance with VFSMOD. Paper No. MC02-308. St. Joseph, MI: American Society of Agricultural Engineers.

Helmers, M.J., D.E. Eisenhauer, T.G. Franti, and M.G. Dosskey. 2005. Modeling sediment trapping in a vegetative filter accounting for converging overland flow. Transactions of the American Society of Agricultural Engineers 48:541-555. 
Herschfield, D.M. 1961. Rainfall Frequency Atlas of the United States. Technical Paper No. 40. Washington DC: US Weather Bureau.

Larson, W.E., M.J. Lindstrom, and T.E. Schumacher. 1997. The role of severe storms in soil erosion: A problem needing consideration. Journal of Soil and Water Conservation 52(2):90-95.

Lee, K.-H., T.M. Isenhart, R.C. Schultz, and S.K Mickelson. 2000. Multispecies riparian buffers trap sediment and nutrients during rainfall simulations. Journal of Environmental Quality 29:1200-1205.

Mander, Ü., V. Kuusements, K. Lõhmus, and T. Mauring. 1997. Efficiency and dimensioning of riparian buffer zones in agricultural catchments. Ecological Engineering 8:299-324.

Muñoz-Carpena, R., and J.E. Parsons. 2000. VFSMOD, Vol. 1.04, User's Manual. North Carolina State University, Raleigh.

Muñoz-Carpena, R., and J.E. Parsons. 2004. A design procedure for vegetative filter strips using VFSMODW.Transactions of the American Society of Agricultural Engineers 47:1933-1941.

Muñoz-Carpena, R., and J.E. Parsons. 2005. VFSMODW: Vegetative Filter Strips Hydrology and Sediment Transport Modeling System v.2.x. Homestead, FL: University of Florida. http://carpena.ifas.ufl. edu/vfsmod.

Muñoz-Carpena, R., J.E. Parsons, and J.W. Gilliam. 1993 Numerical approach to the overland flow process in vegetative filter strips. Transactions of the American Society of Agricultural Engineers 36:761-770.

Muñoz-Carpena, R., J.E. Parsons, and J.W. Gilliam. 1999. Modeling hydrology and sediment transport in vegetative filter strips. Journal of Hydrology 214:111-129.

Muñoz-Carpena, R., Z. Zajac, and Y.M. Kuo. 2007. Global sensitivity and uncertainty analysis of the water quality model VFSMOD-W. Transactions of the American Society of Agricultural and Biological Engineers 50:1719-1732.

NCES (Nebraska Cooperative Extension Service). 1988. Universal Soil Loss Equation: A Handbook for Nebraska Producers. EC88-116. Lincoln, NE: University of Nebraska Institute of Agriculture and Natural Resources.

Overcash, M.R., S.C. Bingham, and P.W. Westerman. 1981. Predicting runoff pollutant reduction in buffer zones adjacent to land treatment sites. Transactions of the American Society of Agricultural Engineers 24:430-435.

Phillips, J.D. 1989. An evaluation of the factors determining the effectiveness of water quality buffer zones. Journal of Hydrology 107:133-145.

Rawls, W.J., D.L. Ahuja, D.L. Brakensiek, and A. Shirmohammadi. 1993. Infiltration and soil water movement. In Handbook of Hydrology, ed. D.R. Maidment, 5.1-5.51. New York, NY: McGraw-Hill.
Sadeghi, A.M., R. Muñoz-Carpena, and C. Graff. 2004 Optimization of buffer-grass criteria as part of national $\mathrm{P}$ index evaluation using VFSMOD-W model. In Abstracts of the 2004 ASA-CSSA-SSSA International Annual Meetings. Madison, WI: American Society of Agronomy. Schmitt, T.J., M.G. Dosskey, and K.D. Hoagland. 1999. Filter strip performance and processes for different vegetation, widths, and contaminants. Journal of Environmental Quality 28:1479-1489.

Suwandono, L., J.E. Parsons, and R. Muñoz-Carpena. 1999. Design Guide for Vegetative Filter Strips using VFSMOD. Paper No. 99-2147. St. Joseph, MI: American Society of Agricultural Engineers.

USDA. 1997. National Handbook of Conservation Practices. Washington DC: USDA Natural Resources Conservation Service. http://www.nrcs.usda.gov/ technical/standards/nhcp.html.

USDA. 2007. Revised Universal Soil Loss Equation: Version 2 (RUSLE). Washington DC: USDA Natural Resources Conservation Service. http://fargo.nserl. purdue.edu/rusle2_dataweb/RUSLE2_Index.htm.

Wischmeier, W.H., and D.D. Smith. 1978. Predicting Rainfall Losses: A Guide to Conservation Planning. Agricultural Handbook No. 537. Washington DC: USDA. 